\title{
Adoption of Mobile Learning: The Influence and Opportunities for Learning During the Covid-19 Pandemic
}

\author{
https://doi.org/10.3991/ijim.v15i05.21067 \\ Leni Pebriantika ${ }^{(凶)}$ \\ Universitas Negeri Jakarta, Jakarta, Indonesia \\ Universitas Baturaja, Baturaja, Indonesia \\ 29leni@gmail.com / leni_pebriantika@fkip.unbara.ac.id \\ Basuki Wibawa, Maria Paristiowati \\ Universitas Negeri Jakarta, Jakarta, Indonesia
}

\begin{abstract}
Research It is designed using quantitative and qualitative approaches. The sampling technique used in this study was purposive sampling. The samples in this study were lecturers and students. Data collection techniques using questionnaires and interviews. Interviews were conducted by interviewing lecturers at several different campuses. The results of the interview show that mobile learning is the learning that students are most interested in because it can be accessed through their cellphones. Quantitative data analysis used the productmoment correlation test. The research subjects consisted of 110 students. The significance level of $0.001(\mathrm{p}<0.05)$ indicates that there is a significant influence between the adoption of mobile learning on student interest in learning during the Covid pandemic 19
\end{abstract}

Keywords-Adoption of mobile learning; covid pandemic 19; online learning; student interests

\section{Introduction}

The Covid 19 pandemic has affected all sectors, including education. At this time there is a need for technology involvement in education or better known as technology education (TE) [1]. The conceptual understanding of technology education has long been conflated. Individuals who look at technology in education may see educational technology, information, and communication technology (ICT), and technology education or trades, with elements of design, applied across disciplines from art to science [2].

During the Covid 19 pandemic, lecturers and students couldn't meet face to face for an indefinite time but the implementation of learning could still be done by adopting mobile learning. About previous studies of m-learning in higher education, different research trends are collected. On the one hand, we find studies focused on the adoption of m-learning [3], [4], [5], [6], [7], [8], [9]. This learning does not immediately 
eliminate conventional methods in lectures, but it needs to be well regulated in its methods and applications.

When talking about mobile learning, users tend to think about electronic devices themselves. The most commonly used portable devices are smartphones, laptops, or notebooks [10]. However, the selection of special enhancements also supports the implementation of mobile learning such as audio, cameras, supporting applications, and others. All of them are technologies that can support mobile learning to its maximum application which can increase the accessibility of learning materials effectively.

For HR or learning and development professionals, mobile learning technology will be seen as a platform such as a learning management system (LMS), a learning experience platform (LXP), or other mobile application training. The newest system will be mobile-friendly by default because it will function properly. on any device. However, how well they consider the unique requirements and mindsets of mobile users will still vary widely.

Mobile learning is an alternative for classroom learning, many studies have been conducted that show that mobile learning can increase student interest in learning and improve the quality of learning. Traditional classrooms have many limitations, such as the limited number of textbooks students can carry and teachers can refer to. In the application of mobile learning, lecturers can use multimedia materials, such as videos and slideshow presentations, students can access them anytime and anywhere, of course, with the systems and conditions that have been agreed upon by the lecturers and students.

From a student perspective, using mobile learning, students can learn and do assignments using media they like or find more effective, such as YouTube videos or podcasts rather than text. This explanation shows that mobile learning is more effective in terms of printing costs of teaching materials, saves implementation time, is more attractive, and is more flexible [11]. The adoption of mobile learning makes it possible fun social learning, in a way that many learners are already comfortable with. In this way, mobile learning can be a very different and more powerful way, to develop new ideas and snowball into innovation. However, whether all students have access to use or study with mobile learning easily, there are still many obstacles that often arise, such as not all mobile devices owned by students are the same in speed and quality. Regarding school education, not all children have mobile devices or are encouraged to use them without restrictions. Things like this are a consideration for lecturers in assessing learning outcomes. Of course, before implementing mobile learning many things have been taken into consideration and solutions that will be given later if these obstacles arise. However, behind the weaknesses of mobile learning, it still provides many benefits in overcoming the learning that occurred during the Covid 19 pandemic [12].

\section{Literature Review}

Mobile learning is learning that utilizes mobile technology and devices, in the form of cell phones, laptops, notebooks, and so on. With mobile learning, users can access learning content anywhere and anytime, without having to visit a certain place at a 
certain time. The learning concept of mobile learning brings the benefits of the availability of teaching materials that can be accessed at any time and the visualization of interesting material. Some of the important abilities that must be provided by m-learning learning devices are the ability to connect to other equipment, especially computers, the ability to present learning information, and the ability to realize communication when it is between instructors and learners [13]. The purpose of adopting mobile learning itself is the learning process all the time, students can be more active in the learning process, save time because if applied to the learning process, students do not need to be present in class just to collect assignments, just send the assignment via the application on the mobile phone. which indirectly will improve the quality of the learning process itself.

\subsection{Mobile learning functions in learning activities}

There are three functions of Mobile Learning in learning activities in the classroom (classroom instruction), namely as a supplement (optional), complementary (complement), or substitute (substitution) [14].

a) Supplements: Mobile Learning serves as a supplement (extra), namely: the students have the freedom to choose whether to take advantage of Mobile Learning material or not. In this case, there is no obligation/obligation for students to access Mobile Learning material. Even though it is optional, students who take advantage of it will certainly have additional knowledge or insight.

b) Complement: Mobile Learning functions as a complement (complement), namely: The material is programmed to complement the learning material received by students in the classroom. This means that Mobile Learning material is programmed to become reinforcement or remedial material for students in following conventional learning activities.

c) Substitution: Some universities in developed countries provide several alternative models of learning activities to students. The goal is that students can flexibly manage their lecture activities according to the time and daily activities of students.

\subsection{Benefits of mobile learning in learning activities}

Mobile Learning provides benefits when viewed from two angles, namely from the point of view of students and educators:

a) Students: Mobile Learning Adoption have high learning flexibility. This means that students can access learning materials at any time and repeatedly. Students can also communicate with lecturers at any time. With these conditions, students can further strengthen their mastery of learning material.

b) Educator: The benefits that can be felt by lecturers with mobile learning are 1) it is easier for lecturers to update learning materials which are their responsibility according to the demands of scientific developments that occur; 2) Developing themselves or doing research to increase their insights because they have relatively a lot of free time; 3) controlling the learning activities of students, even educators/instructors can also find out when their students learn, what topics are studied, how long a topic has 
been studied, and how many times a particular topic is re-learned; 4) check whether students have worked on practice questions after studying a particular topic; 5) checking students' answers and notifying the results to students. The teacher must provide feedback to every learning activity that has been followed by students [15].

Mobile Learning can be used and developed in forming a new learning culture that is more modern, democratic, and educational. Learning culture is a small part of people's culture. Community culture is defined as the integration of all objects, ideas, knowledge, institutions, ways of doing things, habits, patterns of behavior, values, and attitudes of each generation in a society that is accepted by a generation from its predecessor and is often passed on in a changed form to the next generation.

\section{Metodology}

This research was designed using quantitative and qualitative approaches. The sampling technique used in this study was purposive sampling. The sample in this study were lecturers and as many as 110 students who were selected by random sampling technique. Data collection techniques using questionnaires and interviews. Interviews were conducted by interviewing lecturers at several different campuses. The results of the interview show that mobile learning is the learning that is most in demand by students because it can be accessed via students' cellphones. Quantitative data analysis using percentage and simple linear regression.

\section{$4 \quad$ Results and Discussion}

\subsection{Result}

a) Students' level skills in technological literacy: Abilities in the application of mobile learning are very diverse. The number of applications that support learning fosters knowledge and expertise that can support high interest in learning. The level of student expertise in applying the application looks like the following table:

Table 1. Level of students' skills in technological literacy

\begin{tabular}{|c|c|c|c|}
\hline \multirow{2}{*}{ Statement } & \multicolumn{3}{|c|}{ Skills } \\
\hline & Highly & Moderately & Poorly \\
\hline M-device expertise & $91 \%$ & $6 \%$ & $3 \%$ \\
\hline Chatting using social media & $94 \%$ & $5 \%$ & $2 \%$ \\
\hline Sending e-mails & $90 \%$ & $7 \%$ & $3 \%$ \\
\hline YouTube/Live streaming & $89 \%$ & $6 \%$ & $5 \%$ \\
\hline Downloading apps and / e-books & $85 \%$ & $10 \%$ & $5 \%$ \\
\hline Video Conferencing & $92 \%$ & $6 \%$ & $2 \%$ \\
\hline Researching & $83 \%$ & $15 \%$ & $2 \%$ \\
\hline
\end{tabular}

Table. 1 shows that students have very high abilities in learning activities. This is evidenced by the results of a questionnaire that shows M-device expertise $91 \%$, chatting 
using social media 94\%, Sending e-mails 90\%, YouTube / Live streaming 89\%, Downloading apps and / e-books $85 \%$, Video Conferencing $92 \%$ and Researching $83 \%$. These results show that the application of mobile learning can be applied and learning can be followed by students very well.

b) Student perceptions of mobile learning: Adoption of mobile learning during the Covid 19 pandemic has become a learning solution that is widely used by lecturers. Student responses about the implementation of mobile learning are shown in the following figure:

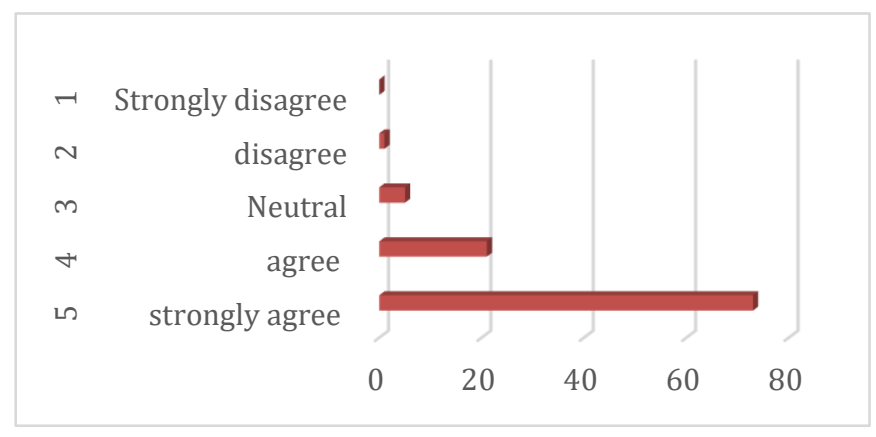

Fig. 1. Student Perceptions of mobile learning

Figure 1 describes students ' perceptions of the implementation of mobile learning. From these results, it can be seen that $73 \%$ of students chose strongly agree, $21 \%$ chose to agree, $5 \%$ chose neutral, $1 \%$ chose to disagree.

c) Hypothesis (The effect of mobile learning adoption on student interest in learning during the Covid 19 pandemic).

Mobile learning is a solution in learning during the Covid 19 pandemic. How influential is mobile learning on student learning interest, the results of the study look like this:

Table 2. Hypothesis

\begin{tabular}{|l|l|c|c|c|c|c|}
\hline \multicolumn{2}{|c|}{ Coefficients } \\
\hline \multirow{2}{*}{ Model } & \multicolumn{2}{|c|}{ Unstandardized Coefficients } & Standardized Coefficients & $\boldsymbol{t}$ & Sig. \\
\cline { 2 - 7 } & B & Std. Error & Beta & & \\
\hline \multirow{2}{*}{1} & (Constant) & 63,472 & 10,237 & & 6,200 &, 000 \\
\cline { 2 - 7 } & Mobile_learning &, 366 &, 106 &, 315 & 3,450 &, 001 \\
\hline \multicolumn{2}{|l}{ a. Dependent Variable: Student_Interest } \\
\hline
\end{tabular}

Table 2. The results of hypothesis testing obtained the probability value Sig. 0.001 $<0.05$, so it can be concluded that there is a significant influence between the application of mobile learning during the Covid 19 pandemic with student interest in learning. 


\subsection{Discussion}

The Covid 19 pandemic that has emerged at this time has become a world issue that affects learning in education. Each educational institution considers the right learning model that must be applied so that learning can still be carried out. One way this is done is by utilizing technology [1]. The most important aspect of future learning is the ease of learning. Mobile Learning has the main potential and characteristics of what is needed by learning in the future. The main thing is based on increasing the power and deployment of mobile devices, and the mass integration of these devices into the world of teaching and learning [14]. The balance that needs to be struck is between embracing new ways of learning and teaching powered by mobile devices while sticking to the basic principles of a good education. One very positive aspect of cellular technology is that it enables learning using cellular technology [16]. Simple examples are google classroom, zoom, WhatsApp which not only provides pages for communicating, learning, sharing videos, and more. but also, a customized mobile app to easily capture and upload this content straight from the learning context.

One of the factors that become the advantages of mobile learning is to make learning easier and faster without the time and place constraints. On the other hand, the mobility that is the mainstay of Mobile Learning allows students to easily interact and discuss learning topics with friends or with lecturers anytime and anywhere [17]. Their free time is used effectively and turned into a valuable time full of useful and positive activities. Also, mobile learning contributes to supporting the interactive characteristics of the learning and teaching environment that make the role of students more effectively through active interaction with teaching and learning materials through mobile sets. Also, it can be said that student achievement and speaking skills have improved because Mobile Learning offers a platform that allows students to explore their abilities.

Mobile learning can support students' private study opportunities with independent access to learning materials and information making it easier to learn. identify individual differences between them. Also, the spontaneity and contextualization of Mobile Learning can make the student-centred teaching process in line with the philosophy of the Constructivist Approach so that they are willing to be able to access teaching content and interact with it [18]. Another important element in successful student learning through Mobile Learning is the opportunities and occasions where students are allowed to access and make use of the vast amount of information available on the Internet for educational purposes and tasks. Mobile learning, in turn, some studies corroborate the effectiveness of m-learning in improving student learning [19]. Furthermore, students perceive it as a useful tool for their learning, since it favours self-regulation [20]. Therefore, the possibility that learning allows being connected at any time and place, has a direct impact on the self-management of learning by the student, where they are the ones who establish the schedule and time that best suits their individual needs to perform the tasks. 


\section{Conclusion}

The main objective of this study is to determine the effects and opportunities of adopting Mobile Learning on student interest in learning during the COVID-19 pandemic. From research conducted during learning by adopting mobile learning, it shows positive results and helps students in learning. During the Covid 19 pandemic learning activities in the classroom were eliminated. The government and universities must think about ways to overcome this problem. Lecturers are required to choose the appropriate learning method for students, with the hope that the applied method can increase student interest in learning. Students are expected to be able to study well even though the distance and learning time difference can be adjusted according to circumstances.

One alternative that is widely used by lecturers is the adoption of mobile learning. Mobile learning provides opportunities for students to study using only their smartphones. Via mobile devices anytime and anywhere. Teachers, on the other hand, can upload files, teaching materials, hold discussions, and students can study and work on assignments with electronic and online assistance.

Students can continue to learn even in the conditions of the Covid-19 pandemic. The adoption of mobile learning provides opportunities for the government, universities, lecturers, and students to continue to increase their interest in learning. Based on the findings of this study, it is recommended that:

a) Mobile learning can continue to be implemented not only during the Covid 19 pandemic.

b) Mobile learning is one of the media that can be used in learning, especially during the Covid pandemic 19

c) The adoption of mobile learning helps students take advantage of free time and turn it into productive activities.

d) The adoption of mobile learning trains lecturers in producing teaching materials and preparing courses with features that can attract student learning interest.

\section{Acknowledgement}

This research work is supported by the Ministry of Research, Technology, \& Higher Education, Indonesia (Doctoral Dissertation Research scheme of Universitas Negeri Jakarta).

\section{$7 \quad$ References}

[1] Code, J., Ralph, R., \& Forde, K. (2020). Pandemic designs for the future: perspectives of technology education teachers during. 121(5), 419-431. https://doi.org/10.1108/ILS-042020-0112

[2] Petrina, S. (2007), Advanced Teaching Methods for the Technology Classroom, Information Science Publishing, Hershey, PA. https://doi.org/10.4018/978-1-59904-337-1 
[3] Fagan MH (2019) Factors influencing student acceptance of mobile learning in higher education. Comput Sch 36(2):105-121. https://doi.org/10.1080/07380569.2019.1603051

[4] Hoi VN (2020) Understanding higher education learners' acceptance and use of mobile devices for language learning: a Rasch-based path modeling approach. Comput Educ 146:103761. https://doi.org/10.1016/j.compedu.2019.103761

[5] Kumar JA, Bervell B (2019) Google classroom for mobile learning in higher education: modeling the initial perceptions of students. Educ Inf Technol 24:1793-1817. https://doi.org/10.1007/s10639-018-09858-Z

[6] Gómez-Ramírez I, Valencia-Arias A, Duque L (2019) Approach to M-learning acceptance among university students: An integrated model of TPB and TAM. IRRODL 20(3):141-164. https://doi.org/10.19173/irrodl.v20i4.4061

[7] López FA, Silva MM (2016) Factors of mobile learning acceptance in higher education. Estud Sobre Educ 30:175-195. https://doi.org/10.15581/004.30.175-195

[8] Saroia AI, Gao S (2019) Investigating university students' intention to use mobile learning management systems in Sweden. Innov Educ Teach Int 56 (5):569-580. https://doi.org/10.1080/14703297.2018.1557068

[9] Kaliisa R, Palmer E, Miller J (2019) Mobile learning in higher education: A comparative analysis of developed and developing country contexts. Br J Educ Technol 50(2):546-561. https://doi.org/10.1111/bjet.12583

[10] Göksu, İ., \& Atici, B. (2013). Need for Mobile Learning: Technologies and Opportunities. Procedia - Social and Behavioral Sciences, 103, 685-694. https://doi.org/10.1016/j.sbspro. $\underline{2013.10 .388}$

[11] Ken Nee Chee, Noraffandy Yahaya, Nor Hasniza Ibrahim, \& Mohamed Noor Hasan. (2017). Review of Mobile Learning Trends 2010-2015: Journal of Educational Technology \& Society, 20(2), 113-126. Retrieved from http://www.jstor.org/stable/90002168

[12] Biswas, B., Roy, S. K., \& Roy, F. (2020). Students' Perception of Mobile Learning during COVID-19 in Bangladesh: University Student Perspective Students Perception of Mobile Learning during COVID-19 in Bangladesh: University Student Perspective. (July). https://doi.org/10.29333/aquademia/8443

[13] Sönmez, A., Göçmez, L., Uygun, D., \& Ataizi, M. (2018). A review of current studies of mobile learning. Journal of Educational Technology \& Online Learning, 1(1), 12-27. https://doi.org/10.31681/jetol.378241

[14] Pebriantika, L., Paristiowati, M., \& Mochtar, H. (2019). Students' Perceptions of Mobile Technology in Higher Education: Preparation to Design Mobile Learning Models. Universal Journal of Educational Research, 7, 180-185. https://doi.org/10.13189/ujer.2019.071621

[15] Ada, M. B., Stansfield, M., \& Baxter, G. (2017). Article information: Journal of Applied Research in Higher Education, 9(1), 70-90. https://doi.org/10.1108/JARHE-07-2015-0060

[16] Aznar-díaz, I. (2020). Models of good teaching practices for mobile learning in higher education. Palgrave Communications, (2020). https://doi.org/10.1057/s41599-020-0468-6

[17] Botzer, G., \& Yerushalmy, M. (2008). Mobile Application for Mobile Learning. Cognition and Exploratory Learning in Digital Age, (Celda), 36-42

[18] Ibrahim, A., Elfeky, M., Saleem, T., \& Masadeh, Y. (2016). The Effect of Mobile Learning on Students' Achievement and Conversational The Effect of Mobile Learning on Students' Achievement and Conversational Skills. (May). https://doi.org/10.5430/ijhe.v5n3p20

[19] Bai H (2019) Pedagogical practices of mobile learning in K-12 and higher education settings. TechTrends 63:611-620. https://doi.org/10.1007/s11528-019-00419-w

[20] Hossain S, Abdou BO, Kettunen J, Gregory S (2019) A phenomenographic research study of students' conceptions of mobile learning: an example from higher education. SAGE Open 1-17. https://doi.org/10.1177/2158244019861457 


\section{Authors}

Leni Pebriantika is a student at the Doctoral Program of Educational Technology, Universitas Negeri Jakarta, Indonesia. She is also a lecturer at the Department of Educational Technology, Universitas Baturaja, Indonesia. Research Interest: Mobile Learning, Educational technology, and technology-based learning. Email: 29leni@gmail. com

Basuki Wibawa is a Professor at Universitas Negeri Jakarta, Indonesia. Research Interest: Mobile Learning, Blanded Learning, educational technology, instructional media, classroom action research, development research, and research related to technological development. He is the author of books on research methodology, educational technology and innovation in Education. Email: bwibawa@unj.ac.id

Maria Paristiowati is a lecturer at the Department of Chemistry Education, Universitas Negeri, Indonesia. Research Interest: Chemistry Education, Educational Technology, TPACK, Lesson Study, Science Education, Higher Order Thinking Skills, STEM Education. Course Taught: Thermodynamics, Kinetics, Polymer, Microteaching, Media of Teaching and Learning Chemistry, Analysis of Chemistry Curriculum, Methodology of Teaching and Learning Chemistry, ICT in Chemistry Learning. Bachelor's degree in Chemistry Education - Universitas negeri Jakarta, Indonesia (1991) . Master's degree in Chemistry - Bandung Institute of Technology, Bandung, Indonesia (2001). Doctoral degree in Educational Technology - Universitas negeri Jakarta, Indonesia (2015). She is the head of the Best Study programme at the Universitas negeri Jakarta, Indonesia. Email: maria.paristiowati@unj.ac.id

Article submitted 2021-01-12. Resubmitted 2021-02-23. Final acceptance 2021-02-24. Final version published as submitted by the authors. 